Ключевые слова: орфографика, романистика, научная деятельность, преподаватель, французский язык, общественный деятель.

Stanislav Olha, Brytvin Dmytro. Development of Spelling, Graphical Stylistics and Francophonie in Ukraine Essay on life and activities. To the $\mathbf{7 5}^{\text {th }}$ anniversary of the birth of Professor H. H. Kriuchkov. The article is dedicated to a real intellectual, a famous Ukrainian scientist of romance studies, a talented professor, Head of the Department of Romance Philology of the Institute of Philology of the Taras Shevchenko National University of Kyiv, Doctor of Philology, Professor, Honored Worker of Education of Ukraine Heorhii Kriuchkov. For more than half a century H. Kriuchkov successfully combines teaching, scientific, educational and public activities. The professor nobly serves philology in the field of education, science and culture, promotes the French language and Francophone values in Ukraine.

Under the leadership of Professor Kriuchkov H. defence more than one $\mathrm{PhD}$ and doctoral dissertations. He is known and respected in scientific circles of Ukraine and abroad. The professor's publications are often cited, and his thoughts and ideas inspire scientists to new scientific achievements. The results of the author's research attracted the attention of French, Swiss, German and Dutch researchers, who offered to start cooperation with foreign universities.

In his teaching career, $\mathrm{H}$. Kriuchkov has always paid much attention and importance to the methods of teaching foreign languages. He was a supporter of building textbooks on a communicative basis using new methods of teaching foreign languages and developed his own system-communicative approach with subsequent foreign language activities.

Kriuchkov Heorhii is constantly in scientific research, participates in scientific conferences, symposia, round tables, colloquia, which are held in Ukraine and in other countries. He initiates new and new scientific-practical and creative projects, initiates francophone events of various levels.

Heorhii Kriuchkov is the embodiment of the image of a real scientist, a professor with a capital letter, a person with an active social position. Everyone who is lucky to work, study, communicate, with him, respects and appreciates him for such personal qualities as integrity and honesty, kindness and tact, sincerity and gentleness. Scientific, pedagogical and public activity of Kriuchkov H. is marked by our state and France by numerous awards and gratitude.

Today, Heorhii Kriuchkov is one of the leading Ukrainian scientist of romance studies, who educated several generations of philologists and made a significant contribution to the domestic humanities.

Key words: spelling, Romance philology, teacher, French, public activist.

DOI: https://doi.org/10.32782/2410-0927-2020-13-25

УДК $811.111 ’ 373.23$

Лариса Тараненко, Слизавета Шестопал

\title{
ЛІНГВАЛЬНІ ОСОБЛИВОСТІ ВЖИВАННЯ ПРЕЦЕДЕНТНИХ ІМЕН У СУЧАСНІЙ АНГЛОМОВНІЙ ЛІТЕРАТУРІ
}

У статті розглянуто особливості вживання прецедентних імен в англійській мові шляхом висвітлення закономірностей їх мовностилістичного вираження у творах сучасної художньої літератури. Аналіз ілюстративного матеріалу здійснено на основі узагальненої класифікації типів і видів прецедентних імен, яка охоплює їх поділ за критерієм належності до певної соціокультурної групи (універсально-прецедентні, національно-прецедентні й соціумно-прецедентні), а також за семантичним критерієм (прецедентні антропоніми та топоніми; термінологічні й полісемічні прецеденти). Серед найчисленніших еталонних тематичних груп прецедентних імен зареєстровано імена історичних осіб, героїв класичних творів і фільмів та міфологеми, які реалізуються в тексті через низку стилістичних фігур, таких як метафора, гіпербола й порівняння. До провідних критеріїв, котрі слугують основою для розрізнення прецедентних феноменів від інших імен, відносимо апелювання до ознак зовнішності осіб або персонажів, рис їхнього характеру або комунікативних ситуацій, через які проявляється знаковість героя або видатної особи. За результатами аналізу з'ясовано, що прецедентні імена як одна з вербальних форм відображення стереотипнометафоричного сприйняття дійсності певною культурною спільнотою людей демонструють тенденцію до розширення свого контекстуального значення та примноження характеристик завдяки здатності формувати ментальні зв'язки між їхнім першоджерелом і новим контекстом. Виконане дослідження ілюстративного матеріалу засвідчило, що прецедентні імена належать до дієвих засобів привернення уваги читача до певної ідеї твору й слугують засобом інтенсифікації конкретних рис та особливостей персонажів художньої літератури XXI ст. Перспективним убачається вивчення питань, пов'язаних із сугестивним й емоційно-прагматичним потенціалами прецедентних імен, а також поглиблення знань про перебіг синергетичних процесів під час їх породження та актуалізації в межах різних лінгвокультур.

Ключові слова: прецедентне ім'я, класифікація, стилістичний прийом, англомовна художня література, функціональне призначення.

Вступ. Сучасному розвитку лінгвістики притаманна зміна векторів іï дослідницьких парадигм, які характеризуються поглибленим вивченням динаміки розвитку мовних i

(C) Тараненко Л., Шестопал С., 2020 
мовленнєвих феноменів, використовуючи надбання суміжних із лінгвістикою галузей знання. До одного 3 таких явищ належать і прецедентні імена як центральні елементи системи прецедентних феноменів, що набувають статусу прецедентності в певних умовах комунікації під впливом низки соціо- й лінгвокультурних факторів. Дослідженням специфіки функціонування прецедентних імен у художньому, науковому, медійному, релігійному та інших дискурсах займалися вітчизняні й зарубіжні науковці різних галузей лінгвістичного знання (Т. С. Бистрова, О. О. Ворожцова, Ю. Н. Караулов, А. С. Супрун, Є. А. Нахімова та ін.). Так, різний ступінь опрацювання отримали питання класифікації прецедентних явищ i ïx категоризації (В.В. Красних, Д.Б. Гудков), омонімії прецедентних імен (С.С. Отин), прецедентних імен як складової частини універсальної когнітивної бази (В. В. Красних) тощо. Отже, на сьогодні накопичено достатньо інформації, яка дає змогу охарактеризувати прецедентні імена через їх типи, види та функціональне призначення. Водночас у наявних лінгвістичних джерелах відсутнє одностайне розуміння феномену прецедентного імені як однієї з вербальних форм відображення стереотипно-метафоричного сприйняття дійсності певною культурною спільнотою людей, що уможливило б б обгрунтування специфіки його вживання в сучасній англомовній художній літературі, що й визначає актуальність започаткованого нами дослідження.

Мета роботи - установлення особливостей уживання прецедентних імен у сучасній англомовній художній літературі шляхом виявлення їхніх мовностилістичних ознак.

Матеріал та методика дослідження. Для досягнення поставленої мети сформовано корпус із 92 прецедентних імен, відібраних методом суцільної вибірки з англомовних художніх творів XXI ст. Етапи дослідження охоплювали систематизацію текстових фрагментів, у яких уживалися прецедентні імена, за прагматичною спрямованістю, і лінгвостилістичний аналіз кожної групи прецедентних імен, спрямований на встановлення їхніх лексико-семантичних ознак, прагматичного потенціалу й ступеня пізнаваності.

Результати та дискусії. Прецеденті імена як окреме поняття сформувалися з феномену прецедентного тексту, запропонованого Ю. Н. Карауловим. При цьому зазначаємо, що прецедентні імена вирізняються емоційно-прагматичним потенціалом та високим ступенем пізнаваності в процесі формування зв'язків між контекстом, у якому використано таке ім'я, i контекстом його актуалізації в першоджерелі [7, с. 17]. Еталонність прецедентних імен є мірилом цінностей суспільства певного історичного періоду та основою для побудови достовірної картини світу. Сприяючи стереотипізації, прецедентні імена актуалізуються в процесі соціалізації шляхом регулярного звернення до них у межах певного дискурсу.

Визначаючись як функціонально-прагматична одиниця, прецедентне ім'я слугує засобом провокації пізнавальної діяльності реципієнта, створення ефекту комічності за накладання різноманітних типів дискурсів і розвитку подальшої сюжетної лінії твору [6, с. 24]. При цьому залежно від соціокультурного контексту, у якому вживаються прецедентні імена, вони можуть виконувати й окремі $з$ наведених функцій, і їхні комплекси. Зазначаємо також, що аналіз функціонального призначення прецедентних феноменів має розглядатися не лише в контексті твору, але й з урахуванням більш широкого соціокультурного контексту [1, с. 227].

Розрізнення прецедентних феноменів взагалі й прецедентних імен зокрема являє собою складну систему сплетіння критеріїв та векторів розгляду цієї проблеми. Тому прецедентні імена мають вивчатися, передусім, у площині їхніх лексико-семантичних ознак, прагматичного потенціалу та ступеня пізнаваності.

Так, у лексико-семантичному плані прецедентні імена тісно взаємодіють із поняттям прецедентних онімів, які, вирізняючись метафоричністю, формують окрему групу прецедентних імен. Спираючись на класифікацію прецедентних онімів, запропоновану С. С. Отин [5, с. 55-58], розглянемо специфіку функціонування їхніх різновидів у сучасних художніх текстах.

Так, уживання прецедентного імені-антропоніма можна проілюструвати на такому прикладі: "Billy holding the one flashlight and playing James Bond, trying to find secret caches of marijuana" (S. King). У цьому контексті прецедентне ім'я, виражене метафорою, надає конкретної образності поведінки персонажа. 
Прикладом прецедентного імені-міфоніма може слугувати фрагмент, у якому за допомогою прецедентного імені більш чітко й однозначно візуалізується образ персонажа: “Не was truly prodigious in stature, an Achilles in the flesh" (E. Gilbert).

Прецедентний топонім спроможний здійснювати зв'язок між відчуттями, викликаними перебуванням у конкретній місцевості, та відчуттями, що переживає персонаж твору, наприклад: "As far as I could tell, she was having more fun with this than a kid locked inside Disneyland overnight" (St. Meyer).

Використання прецедентного імені в ролі хрононіма переносить увагу читача до конкретного часового проміжку або історичного періоду, пов'язаного з тим чи тим іменем, наприклад: "The beaten-up short wave radio in the kitchen belonged to him". "From Brezhnev era," said Boris; "he won't throw it away" (D. Tartt).

Як видно з прикладів, прецедентні імена апелюють саме до еталонних характеристик осіб або персонажів, більш ефективно та влучно транслюючи таким чином ключову інформацію твору.

Вагомий внесок у створення класифікації прецедентних імен за ознакою їх пізнаваності зробили В. В. Красних і Д.Б. Гудков [4], які виокремили такі групи прецедентних імен: соціумно-прецедентні (розповсюджені серед представників певних верств населення чи їх соціокультурних груп), національно-прецедентні (відомі представникам конкретної національної спільноти); універсально-прецедентні (загальновідомі й широко розповсюджені).

Наведені вище міркування, а також інформація 3 інших джерел свідчать, що найчастотнішими серед різновидів прецедентних імен $є$ універсально-прецедентні, особливістю яких, згідно з Д. Б. Гудковим, є наявність у них семантичного інваріанта, присутнього в інших лінгвокультурах [2]. Розглянемо приклади вживання різновидів універсально-прецедентних імен, актуалізованих у контексті сучасної англомовної літератури, загальною кількістю 92 одиниці.

Лінгвостилістичний аналіз художніх творів дає підставу стверджувати, що до найбільш уживаних різновидів прецедентних імен належать антропоніми (34\%), зокрема історизми, представлені іменами історичних діячів, наприклад:

"The wave of faintness has passed, and I can hug Nina, breathing in her particular scent: Jean Paul Gaultier, and cigarettes" (R. Ware), де спостерігаємо звернення до прецедентного імені історичної особистості шляхом їі персоніфікації.

Подібну частку становлять і прецедентні імена, репрезентовані іменами персонажів літератури та кінематографу, які в досліджуваних текстах становлять 34 \%, наприклад: “It's a Goldilocks blow, not too hard, not too soft, just right" (S. Stephen). Цей приклад демонструє метафоричне застосування прецедентного імені, яке можна редукувати до значення «саме той/такий».

Наступними за частотою функціонування в аналізованих нами художніх творах зареєстровано прецеденті імена-міфологеми (20\%): “I thought, staring at the grim-faced girl who was less Venus than a sour housekeeper" (J. Moyes). Наведений приклад наочно проводить паралелі між зображенням дівчини та Венери, додаючи образності та контрастності до їхніх постатей.

Щодо прецедентних імен-біблеїзмів, то їх частка становить 7 \%. Прикладом актуалізації імен-біблеїзмів може слугувати фрагмент, у якому проілюстровано метафоричне використання біблейського прецедентного імені для підвищення могутності й необмежених можливостей Радянського Союзу: “A war between Afghanistan's mujaheddin freedom fighters and the mighty Goliath of the Soviet Union" (G. D. Roberts).

Наступними за частотою реалізацій зареєстровано топоніми (5\%), які слугують метафоричному розкриттю специфічних ознак описуваного об'єкта: “I was standing there forever and no one at desk. No one! Sahara Desert!" (R. Ware) (Сахара - пустинне місце, біля столу не було ні душі).

На нашу думку, таке часте використання власних назв імен пов'язане зі стереотипізацією образів. Ім'я особи чи персонажа вбирає в себе сукупність характерних рис, дозволяючи ефективніше втілювати новий контекст в уже відомий. За основні риси можуть братися різні 
ознаки, серед яких найчастіше трапляються звернення до зовнішніх рис людей або персонажів, особливостей їхнього характеру або ж через ситуацію, у якій опиняється герой.

Зі свого боку, термінологічні імена, згідно з В. В. Красних, - це прецедентні імена, що розкриваються через асоціативний ряд зовнішніх рис персонажів або рис їхнього характеру $[4$, с. 81]. Вони часто походять від імен героїв міфів, легенд і персонажів літератури й кінематографу. Наведені нижче приклади - свідчення того, як автори залучають до опису прецедентні термінологічні імена задля транслювання вже відомого читачеві образу:

"I lay with my arm across the chaise longue, my body twisted like the reclining Aphrodite he showed me in a book, my skirt gathered in folds over my legs" (J. Moyes).

"...who has never cared about her until that moment, falls in love with her because she looks like a Botticelli girl from a slightly damaged fresco" (D. Tartt).

"Sopping wet in just a T-shirt, jeans, and baseball boots, he was still grinning like the Cheshire cat peeping over Alice's shoulder" (R. Hogan).

"I could feel that my hair was wild, twisted into clumps like Medusa's snakes" (St. Meyer).

"The stony hills draw together in front of us like the gates of an abandoned Hades" (G. Howell).

Для візуалізації образу автори звертаються й до інших засобів, серед яких здебільшого метафори, наприклад:

"Off in the west, silent Frankenstein flashes of lightning twisted in the darkness" (D. Tartt).

"Her pale skin stretched so flawlessly over the soft curves of her heart-shaped face that for a moment, in the bright white light, she was a furious, marble Madonna" (G. D. Roberts).

"It probably felt similar to snuggling with Michelangelo's David, except that this perfect marble creature wrapped his arms around me to pull me closer" (St. Meyer).

Оскільки за своїм прагматичним потенціалом імена можуть набувати або не набувати прецедентності, так і термінологічні прецедентні імена бувають полісемічними, актуалізуючись не через ознаки, а через знакові ситуації. Такі імена проявляються через паралелі, проведені між широко відомою ситуацією та ситуацією нового контексту прецедентного імені, як це видно 3 наведених нижче прикладів:

“We don't have some great weakness, an Achilles' heel' (St. Meyer).

"...every appearance of being a goddess in captivity-Aphrodite trapped in a convent" (E. Gilbert).

"Conan Doyle could find no wilder place to set the disappearance of Sherlock Holmes than the nearby Reichenbach Falls" (G. Howell).

"I heard later that someone said we were like David against Goliath, except we didn't even have a slingshot" (N. Sparks).

"...but it's a job for Hercules" (G. Howell).

Підсилення емоційної напруги описуваної ситуації досягається шляхом обрамлення полісемічних прецедентних імен у порівняльні вирази, наприклад:

"...followed the notes like Ariane's thread through a labyrinth I had ceased to recognize" (D. Setterfield).

"I felt if I looked at him any longer I should be like Byron and the goose" (G. Howell).

"I went, stumbling like Frankenstein's monster before pitchforks" (D. Tartt).

"...I lie on one of the beds upstairs, like Goldilocks, only I never sleep" (S. Green).

Охарактеризуємо універсально-прецедентні імена, які є ядерними складовими частинами універсальної когнітивної бази та які В. В. Красних характеризує як структуровану сукупність знань й уявлень носіїв певного соціокультурного середовища [3, с. 130]. Оскільки універсальнопрецедентні імена здатні формувати зв'язки між першоджерелом та новим контекстом, то потрібно врахувати часовий фактор появи таких імен, які можуть потенційно вважатися прецедентними. Тому, зазвичай, до універсально-прецедентних імен належать імена, запозичені 3 класичних творів літератури й із фольклору. У процесі використання таких імен автор прирівнює прецедентне ім'я героя з персонажем або ситуацією в новому контексті, як це видно 3 наведених прикладів:

"It was as if malignant fate had come between him and the notebooks, just as fate had come between Romeo and Juliet" (D. Keyes).

"Like Scheherazade, she would win his attention and then his love by her spellbinding 
storytelling and the sheer force of the adventure" (G. Howell).

"Okay, Rapunzel. If you're going to stick around in this tower of yours, you're going to have to let the odd prince run his fingers through your hair" (J. Moyes).

"My goodness, you've grown!" and "that hair! Like Mowgli the Jungle Boy!" (D. Tartt).

"Even Sherlock Holmes could not reach me in the snowlocked landscape" (D. Setterfield).

Щодо імен видатних осіб, а також імен персонажів сучасного кінематографу й літературних творів, то вони піддаються мінливості та плинності. Щоб стати еталонним іменем і зафіксуватись у свідомості носіїв мови, образ персонажа має бути унікальним і неповторним, а особа має бути яскравою. Проаналізувавши приклади, наведені нижче, можемо узагальнити, що персоналії прецедентних імен персонажів й історичних осіб використовуються, щоб наблизити нових персонажів до рівня величі носіїв цих імен, як видно з прикладів:

“God, I feel like Jason Bourne,' he said. 'I can literally feel the power going to my head as I speak" (R. Ware).

"At this point, I was ready for almost anything—some kind of James_Bond villain's high-tech lair seemed appropriate" (St. Meyer).

(E. Gilbert).

"Rather, she strode into Henry's study like Joan of Arc, and stood before her father undaunted" (M. Dobbs).

"...he smiled a huge, theatrical smile like Macbeth welcoming dinner guests 'it can't be helped"

Водночас прецедентні імена можуть бути також задіяні для споріднення певних ознак між новим контекстом й іменем, що використовується. Така прагматична мета досягається варіаціями низки стилістичних засобів. Так, наприклад, у поданому нижче висловленні прецедентне ім'я виступає метафорою, філігруючи візуальний образ персонажа: Roberts).

"Even Didier, in his crumpled-up way, has got a touch of the Lord Byron about him" (G. D.

Гіперболізація шляхом використання прецедентного імені спрямована на підвищення захоплення читача персонажем: “...owned a library that would have made a Medici weep with longing" (E. Gilbert).

Проведення паралелей між декількома прецедентними іменами й комунікативною ситуацією підсилює загальну ідею твору, як от у поданому фрагменті, де пари прецедентних імен акцентують увагу читача на неминучій зраді:

"Jared glared balefully at the old man, his eyes full of the shock and pain of the betrayed. I had only human comparisons for such a look. Caesar and Brutus, Jesus and Judas" (St. Meyer).

Типовою відмінністю прецедентних імен від інших прецедентних феноменів $\epsilon$ залучення до репрезентації загальної ідеї зовнішніх рис і невербальних образів як основи еталонності. До таких ознак можемо віднести й візуальну презентацію відомого мистецького твору, і аудіальні ознаки, що проявляються у вигляді паралелей, про що свідчать наведені нижче приклади: (D. Tartt).

"...falls in love with her because she looks like a Botticelli girl from a slightly damaged fresco"

"She wore no sunglasses today, but her eyelids were colored purple, lined Cleopatra-style with kohl and fringed with the same heavy black lashes as yesterday" (D. Setterfield).

"His voice had never been melodious, but it was now uglier than ever: like the rumble of the Devil's belly" (Cl. Barker).

"Her cheeks are round and rosy, with high cheekbones that make her look like Nefertiti, and her mouth as she smiles is wide and warm and generous" (R. Ware).

"All right then," she said in what I thought of as her Mary Poppins voice" (D. Tartt).

"The crowd gasped, and when she rose to the surface, water streaming from her form in ways that recalled the birth of Venus, they gasped again" (D. Setterfield). (St. Meyer).

"The wide-eyed, full-lipped face would make a Botticelli angel look like a gargoyle"

Стилізація прецедентного імені як метафори реалізує безпосереднє звернення до однієї $з$ характерних ознак прецедентного імені, наприклад:

"...when he was drunk, his footsteps slowed to a jarring and unmistakable cadence - 
Frankenstein steps, as I thought of them, deliberate and clumping, with absurdly long pauses between each footfall" (D. Tartt).

"It is a natural, Darwinian process" (D. Keyes).

"If she rings we can be in a taxi before you can say Gérard Depardieu" (J. Moyes).

"...in the atrium of White Acre, relaying in Homeric detail the trials of his coach" (E. Gilbert).

"In this country the women lift the veil of a Raphael Madonna to look at you" (G. Howell).

"Bella, you look like you just stepped out of an Austen movie" (St. Meyer).

Наведені вище приклади свідчать, що використання прецедентних імен в описових контекстах сучасних художніх творів сприяе перенесенню певних еталонних ознак на новий літературний образ, виокремлюючи певні риси персонажів та підсилюючи загальне емоційнопрагматичне спрямування твору.

Висновки. Виконаний аналіз засвідчив, що сучасні англомовні художні твори вирізняються широким використанням прецедентних імен, більшість серед яких посідають універсально-прецедентні. 3'ясовано, що прецедентні імена можуть мати різноманітне походження (антропоніми, міфоніми, біблеїзми, топоніми) та актуалізуватися через низку вербальних і невербальних ознак. У контексті художнього твору прецедентні імена набувають стилістичного забарвлення, функціонуючи в ролі метафори, порівняння й гіперболи. Кількісний аналіз частоти актуалізації прецедентних імен, уживаних у художніх літературі, показав, що найчисленнішими серед них є імена історичних діячів, персонажів літератури й кінематографу, міфологічних і біблійних осіб.

До перспективних напрямів подальшого наукового пошуку в галузі дослідження специфіки функціонування прецедентних імен потрібно віднести вивчення питань, пов'язаних 3 їхнім сугестивним та емоційно-прагматичним потенціалом, а також поглиблення знань щодо перебігу синергетичних процесів породження й актуалізації прецедентних імен у межах різних лінгвокультур.

References:

1. Bystrova, Tatiana. 2016. "Opyt klassifikatsii pretsedentnykh imen (Fel'eton A. P. Chekhova 'V Moskve')". Yaroslavskiy pedagogicheskiy vestnik 2: 225-30.

2. Gudkov, Dmitrij. 2003. Teoriya i praktika mezhkulturnoi kommunikatsii. Moscow: ITDGK "Gnosis."

3. Krasnykh, Viktorija. 1997. "Kognitivnaya baza vs kulturnoe prostranstvo v aspekte izucheniya yazykovoy lichnosti (k voprosu o russkoy kontseptosfere)". Language, Consciousness, Communication 1: 192.

4. Krasnykh, Viktoriya. 2002. Etnopsikholingvistika i lingvokulturologiya. Moscow: ITDGK "Gnozis".

5. Otin, Evgenij. 2003. "Konnotativnye onimy $\mathrm{i}$ ikh proizvodnye $\mathrm{v}$ istoriko-etimologicheskom slovare russkogo yazyka". Voprosu yazykoznaniya 2: 55-72. URL: http://vja.ruslang.ru/ru/archive/2003-2/55-72.

6. Saksonova, Julija. 2001. Pretsedentnyy intertekst: problema mezhyazykovoy ekvivalentnosti v khudozhestvennom perevode (na materiale angliyskogo, nemetskogo i russkogo yazykov). Ekaterinburg.

7. Suprun, Adam. 1995. "Tekstovye reministsentsii kak yazykovoe yavlenie". Voprosy yazykoznaniya 6: 17-29.

8. Barker, Clive. 1992. The Thief of Always. New York: Harper Collins Publishers.

9. Dobbs, Michael. 2015. To Play the King. London: Harper.

10. Gilbert, Elizabeth. 2016. Signature Of All Things. New York: Trivion Books.

11. Green, Sally. 2014. Half Bad. New York: Viking, An Imprint of Penguin Group.

12. Hogan, Ruth. 2017. The Keeper of Lost Things. London: Two Roads.

13. Howell, Georgina. 2008. Gertrude Bell : Queen of the Desert, Shaper of Nations. New York: Farrar, Straus And Giroux.

14. Keyes, Daniel. 1995. The Minds of Billy Milligan. New York: Bantam Books.

15. King, Stephen. 2016. Finders Keepers. London: Hodder.

16. Meyer, Stephenie. 2006. New Moon. Book 2: Twilight Saga Series. Copy 2. New York: Little, Brown And Co.

17. Meyer, Stephenie. 2007. Twilight. Book 3: Eclipse. New York: Little, Brown And Co.

18. Meyer, Stephenie.2008. Twilight. Book 4: Breaking Dawn. New York: Little, Brown.

19. Meyer, Stephenie. 2010. The Host. London: Turtleback Books.

20. Moyes, Jojo. 2014. The Girl You Left Behind. New York: Penguin Books.

21. Roberts, Gregory David. 2004. Shantaram. London: Abacus.

22. Setterfield, Diane. 2006. The Thirteenth Tale. London: Orion.

23. Sparks, Nicholas. 2011. Best Of Me. S.L.: Grand Central Pub.

24. Tartt, Donna. 2013. The Goldfinch. New York: Little, Brown And Company.

25. Ware, Ruth. 2016. In a Dark, Dark Wood. New York: Gallery/Scout Press.

Тараненко Лариса, Шестопал Елизавета. Лингвистические особенности употребления прецедентных имен в современной англоязычной литературе. В статье рассматриваются особенности употребления 
прецедентных имен путем освещения закономерностей их стилистического выражения в произведениях современной англоязычной художественной литературы. Анализ иллюстративного материала базировался на обобщенной классификации прецедентных имен, охватывающей их разделение по критерию принадлежности к социокультурной группе определенного уровня (универсально-прецедентные, национально-прецедентные и социумно-прецедентные), а также по семантическому критерию (прецедентные антропонимы и топонимы; терминологические и полисемические прецеденты). Среди наиболее многочисленных эталонных тематических групп прецедентных имен зарегистрированы имена исторических личностей, героев классических произведений и фильмов, мифологемы, реализующиеся в тексте через ряд стилистических фигур, таких как метафора, гипербола и сравнения. К ведущим критериям, служащим основанием для различия прецедентных феноменов от других имен, относим апеллирование к признакам внешности людей или персонажей, черт характера или коммуникативных ситуаций, через которые проявляется знаковость героя или выдающейся личности. Прецедентные имена, будучи одной из вербальных форм отражения стереотипно-метафорического восприятия действительности определенной культурной общностью людей, демонстрируют тенденцию к расширению своего контекстуального значения и приумножению характеристик, благодаря своей способности формировать ментальные связи между первоисточником и новым контекстом. Выполненный анализ иллюстративного материала показал, что прецедентные имена относятся к действенным средствам привлечения внимания читателя к определенной идее произведения, а также интенсификации конкретных черт и особенностей персонажей художественной литературы XXI в. К перспективным направлениям относим изучение вопросов, связанных с суггестивным и эмоциональнопрагматическим потенциалами прецедентных имен, а также углублением знаний о синергетических процессах их порождения и актуализации в рамках различных лингвокультур.

Ключевые слова: прецедентное имя, классификация, стилистический прием, художественная литература, функциональное назначение.

Taranenko Larysa, Shestopal Yelyzaveta. Lingual Specificity of Precedent Names Used in Modern English Literature. The paper is focused on the study of specificities of precedent names' use in modern English by means of highlighting the patterns of their linguistic and stylistic expression in the works of present-day English fiction. Being studied in various discourses, precedent names are underrepresented in recent linguistic works. The illustrative material is carefully reviewed on the basis of the generalized classification of precedent names, covering their division according to the criterion of belonging to a certain sociocultural group (universal-precedent, national-precedent and socio-precedent names), as well as a semantic criterion (precedent anthroponyms, precedent toponyms; terminological and polysemantic precedents). Among the most numerous thematic groups of precedent names are the registered names of historical figures, heroes of classical literary works, films and mythologies, which are realized in the text through a number of stylistic devices, namely: metaphor, hyperbole and comparison. The key features taken as a basis of the precedent names formation are the following: appeal to the external features of people or characters, specific features of their characters, or the situations in which the character is portrayed. Results of the analysis clearly stated that the most numeric group of precedent names comprises universalprecedent type of names. Viewed as one of the verbal forms of reflection of stereotyped metaphorical perception of reality by a certain cultural community of people, precedent names hold the power to extend their areas of occurrence as they tend to reappear in new context groups. Precedent names expand their contextual meaning due to their ability to form mental connections between the source of their original and the new context. By performing the analysis, it was found out that precedent names belong to the effective means of drawing the reader's attention to a certain idea as well as serve to intensify the specific features and characteristics of the characters of the XXI century fiction. We see it perspective to study the issues related to the emotional-and-pragmatic potential of precedent names, as well as to deepen the knowledge about synergetic processes causing their generation and actualization within different lingual cultures.

Keywords: precedent name, cognitive basis, precedent names, universal precedent names, terminological names, polysemic names.

DOI: https://doi.org/10.32782/2410-0927-2020-13-26

УДК 376.043.2-056.2/.3(477)

Галина Тригуб, Оксана Хникіна

\section{ОСНОВНІ ПРИНЦИПИ ТА ТРУДНОЩІ ЗАПРОВАДЖЕННЯ ІНКЛЮЗИВНОЇ ОСВІТИ У ВИЩИХ НАВЧАЛЬНИХ ЗАКЛАДАХ УКРАЇНИ}

У статті досліджено основні проблеми запровадження інклюзивної освіти у вищих навчальних закладах України. У сучасних умовах доступність вищої освіти для молоді з обмеженими функціональними можливостями $\epsilon$ важливою соціальною й педагогічною проблемою. Інклюзивна вища освіта - один з етапів інтеграції студентів 3 особливими потребами в суспільство, що допомагає їм отримати бажану професію та самореалізуватися в професійній діяльності. У статті висвітлено особливості, завдання й принципи інклюзивної освіти. Окреслено іï базові функції, серед яких найважливішими є правова, функція соціалізації, виховна, освітня та економічна.

(C) Тригуб Г., Хникіна О., 2020 